\title{
ANALISIS KINERJA TIANG DENGAN VARIASI KEMIRINGAN DI DERMAGA "SJ" BANDAR LAMPUNG
}

\author{
Dede Oktaferdian ${ }^{1}$ dan Sunarjo Leman ${ }^{2}$ \\ ${ }^{1}$ Program Studi Sarjana Teknik Sipil, Universitas Tarumanagara, Jl. Letjen S. Parman No.1 Jakarta \\ dede.325170056@stu.untar.ac.id \\ ${ }^{2}$ Program Studi Sarjana Teknik Sipil, Universitas Tarumanagara, J1. Letjen S. Parman No.1 Jakarta \\ sunarjo@ft.untar.ac.id
}

Masuk: 13-07-2021, revisi: 09-10-2021, diterima untuk diterbitkan: 11-11-2021

\begin{abstract}
The design of the jetty cannot be separated from the use of piles as a foundation that supports the upper structure. The pile configuration affects the strength and stability of the structure. It may consist of only vertical piles or a combination of vertical and batter piles. This study analyzes and compares 10 types of pile configurations intending to determine the best pile configuration among the types analyzed. Type 1 is a pile configuration that is in accordance with the field planning of "SJ" jetty which consists of only vertical piles and type 2 to type 10 is a pile configuration that consists of a combination of vertical and batter piles with a slope ranging from $1 \mathrm{H}: 12 \mathrm{~V}$ to $1 H: 4 \mathrm{~V}$. The best configuration is determined based on the strength (capacity ratio), stiffness (deflection that occurs), and the axial bearing capacity of the pile. The process of modeling and analyzing the pile configurations are done using Midas Gen. The results showed that pile configuration type 8 with a combination of vertical and batter piles with a slope of 1H:6V is the best configuration with the smallest deflection and the axial forces of the vertical and batter piles are almost equal.
\end{abstract}

Keywords: foundation pile; batter pile; pile configuration; axial force; deflection

\begin{abstract}
ABSTRAK
Desain dermaga tidak dapat dipisahkan dari penggunaan tiang sebagai fondasi yang menyangga struktur bagian atas. Konfigurasi tiang berpengaruh pada kekuatan dan stabilitas dari struktur dermaga. Konfigurasi tiang dapat terdiri dari tegak seluruhnya maupun kombinasi antara tiang tegak dan miring. Penelitian ini menganalisis dan membandingkan 10 tipe konfigurasi tiang dengan tujuan mendapatkan konfigurasi tiang terbaik di antara tipe-tipe yang dianalisis. Tipe 1 adalah konfigurasi tiang yang sesuai dengan perencanaan dermaga "SJ" berupa tiang tegak seluruhnya dan tipe 2 hingga tipe 10 adalah konfigurasi kombinasi tiang tegak dan miring dengan kemiringan 1H:12V hingga 1H:4V. Konfigurasi tiang terbaik ditentukan berdasarkan kekuatan (capacity ratio), kekakuan (defleksi yang terjadi), dan daya dukung aksial tiang. Model dan proses analisis dari seluruh konfigurasi tiang menggunakan program Midas Gen. Hasil analisis menunjukkan bahwa konfigurasi tiang tipe 8 dengan kombinasi tiang tegak dan miring dengan kemiringan $1 \mathrm{H}: 6 \mathrm{~V}$ adalah konfigurasi terbaik dengan defleksi terkecil serta gaya aksial tiang tegak dan miring yang hampir sama.
\end{abstract}

Kata kunci: tiang pancang; tiang tegak dan miring; konfigurasi tiang; gaya aksial; defleksi

\section{PENDAHULUAN}

Dermaga adalah suatu bangunan pelabuhan yang digunakan untuk merapat dan menambatkan kapal yang melakukan bongkar muat barang dan naik-turun penumpang. Bentuk dan dimensi dermaga tergantung pada jenis dan ukuran kapal yang bertambat pada dermaga tersebut. Dermaga harus direncanakan sedemikian rupa sehingga kapal dapat merapat dan menambat serta melakukan kegiatan di pelabuhan dengan aman, cepat, dan lancar (Triatmodjo, 2010). Fondasi yang menyangga struktur bagian atas dermaga adalah tiang pancang. Perencanaan konfigurasi tiang pada struktur dermaga sangat berpengaruh terhadap kekuatan dan stabilitas dari dermaga. Terdapat 2 jenis tiang pancang yaitu tiang pancang tegak dan tiang pancang miring (batter pile). Konsep fondasi batter pile memasang tiang fondasi dengan sudut kemiringan tertentu. Dengan konstruksi ini, batter pile memiliki ketahanan terhadap beban lateral yang lebih baik dibandingkan tiang tegak. Hal ini dikarenakan pada batter pile sebagian beban lateral disalurkan dalam beban aksial. Penelitian ini akan menganalisis dan membandingkan 10 tipe konfigurasi tiang. Tipe 1 adalah konfigurasi tiang yang sesuai dengan perencanaan dermaga "SJ" Bandar 
Lampung berupa tiang tegak seluruhnya dan tipe 2 hingga tipe 10 adalah konfigurasi kombinasi tiang tegak dan miring dengan kemiringan 1H:12V hingga $1 \mathrm{H}: 4 \mathrm{~V}$.

Berdasarkan uraian yang telah dikemukakan. masalah yang dapat dirumuskan adalah sebagai berikut:

1. Bagaimana kekuatan tiang dilihat dari capacity ratio untuk setiap tipe konfigurasi tiang pancang.

2. Bagaimana kekakuan tiang dilihat dari defleksi yang terjadi untuk setiap tipe konfigurasi tiang pancang.

3. Bagaimana nilai daya dukung aksial akibat gaya lateral untuk setiap tipe konfigurasi tiang pancang.

4. Bagaimana konfigurasi terbaik di antara 10 perbandingan kemiringan tiang pancang.

Tujuan penelitian yang didapatkan berdasarkan rumusan masalah adalah sebagai berikut:

1. Mengetahui kekuatan untuk masing-masing tipe konfigurasi tiang pancang dilihat dari capacity ratio.

2. Mengetahui kekakuan tiang untuk masing-masing tipe konfigurasi tiang pancang dilihat dari defleksi yang terjadi.

3. Mengetahui nilai daya dukung aksial akibat gaya lateral untuk masing-masing tipe konfigurasi.

4. Mengetahui konfigurasi terbaik di antara 10 perbandingan kemiringan tiang pancang yang telah dianalisis.

Konstruksi batter pile (disebut juga sebagai battered pile atau raked pile atau inclined pile) adalah teknik pemasangan tiang dengan memosisikan tiang pada kemiringan terhadap posisi vertikal dengan sudut tertentu. Tahanan tiang tegak terhadap gaya lateral umumnya sangat kecil jika dibandingkan dengan tahanan vertikal, untuk mengatasi hal ini jika tiang mendukung beban lateral yang relatif besar maka posisi tiang dibuat miring. Dengan tiang yang dimiringkan ini, sebagian atau seluruh gaya lateral akan didukung oleh komponen tahanan tiang ke arah horizontal dari tiang miring tersebut. Selain itu fondasi tiang pancang miring dapat digunakan untuk menaikkan kapasitas daya dukung. Oleh sebab itu, tiang pancang miring biasanya digunakan pada konstruksi yang menerima beban lateral besar seperti abutment jembatan, pilar jembatan, struktur lepas pantai, dan dermaga. Sudut kemiringan tiang terhadap garis vertikal dibuat sebesar mungkin, namun juga harus disesuaikan dengan tipe tiang yang digunakan. Kemiringan tiang yang sering dipakai adalah 1H:12V sampai 5H:12V (H=Horizontal, $\mathrm{V}=$ Vertikal) (Hardiyatmo, 2008). Berdasarkan arah kemiringan batter pile dibagi menjadi 2, yaitu batter pile positif yang berarti tiang dengan kemiringan terhadap garis vertikal searah dengan beban lateral dan batter pile negatif yang berarti tiang dengan kemiringan terhadap garis vertikal berlawanan arah dengan beban lateral (Murthy, 2002). Batter pile umumnya dipakai dengan tujuan meningkatkan daya dukung lateral jika tiang vertikal tidak dapat memberikan daya dukung yang diperlukan (Hannigan, Raushce, Likins, Robinson, \& Becker, 2016). Vertical pile dan batter pile ditunjukkan pada Gambar 1.

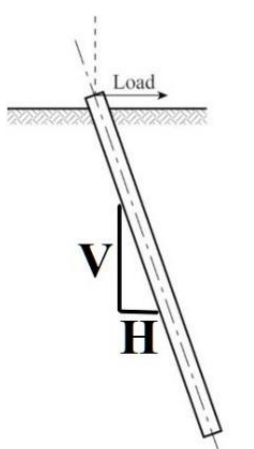

Positive batter pile

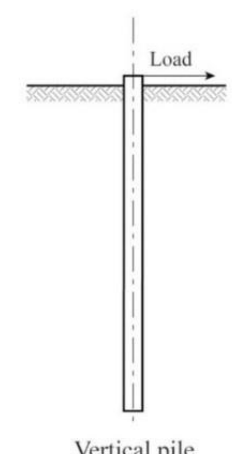

Vertical pile

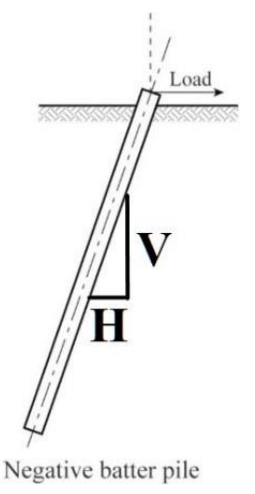

Negative batter pile

Gambar 1. Vertical pile dan batter pile (Sumber: Chegg Study, 2021)

Beban yang bekerja pada dermaga umumnya terdiri dari 7 jenis. Beban mati (dead load) adalah bagian struktur yang bersifat tetap, termasuk berat struktur sendiri. Contohnya balok, kolom, dan pelat lantai. Beban hidup (dead load) adalah semua beban yang dapat berpindah-pindah atau beban yang sifatnya sementara. Contohnya adalah beban alat berat seperti truk, excavator, wheel loader, dan crane. Pada bagian bawah kapal yang terendam dalam air bekerja gaya arus (current load) yang kemudian diteruskan ke tiang pancang dermaga dan alat tambat. Gaya arus pada tiang pancang dihitung dengan Persamaan 1 dan 2 (The Overseas Coastal Area Development Institute of Japan (OCDI), 2002).

Gaya drag:

$$
F_{D}=\frac{1}{2} \times C_{D} \times \rho_{0} \times A \times U^{2}
$$


Dengan $F_{D}=$ gaya drag yang bekerja pada objek yang searah dengan arus $(\mathrm{kN}), C_{D}=$ koefisien drag, $\rho_{0}=$ massa jenis air $\left(\mathrm{t} / \mathrm{m}^{3}\right), A=$ luas yang diproyeksikan dari objek yang searah dengan arus $\left(\mathrm{m}^{2}\right)$, dan $U=$ kecepatan arus (m/det).

Gaya angkat:

$$
F_{L}=\frac{1}{2} \times C_{L} \times \rho_{0} \times A_{L} \times U^{2}
$$

Dengan $F_{L}=$ gaya angkat yang bekerja pada objek tegak lurus dengan arus $(\mathrm{kN}), C_{L}=$ koefisien angkat, $\rho_{0}=$ massa jenis air $\left(\mathrm{t} / \mathrm{m}^{3}\right), A_{L}=$ luas yang diproyeksikan dari objek tegak lurus dengan arus $\left(\mathrm{m}^{2}\right)$, dan $U=$ kecepatan arus $(\mathrm{m} / \mathrm{det})$.

Kapal masih memiliki kecepatan saat merapat ke dermaga sehingga akan terjadi benturan antara dermaga dengan kapal. Beban benturan ini disebut juga sebagai berthing load. Dalam desain dianggap benturan maksimum terjadi jika kapal bermuatan penuh menghantam kapal pada sudut $10^{\circ}$. Gaya benturan kapal yang harus ditahan oleh dermaga bergantung pada energi benturan yang diserap sistem fender pada dermaga. Besar energi benturan yang diberikan oleh kapal dihitung dengan Persamaan 3 (The Overseas Coastal Area Development Institute of Japan (OCDI), 2002).

$$
E_{f}=\left(\frac{M s \times V^{2}}{2}\right) \times C_{m} \times C_{e} \times C_{s} \times C_{c}
$$

Dengan $E_{f}=$ energi benturan kapal $(\mathrm{kNm}), \mathrm{M}_{\mathrm{s}}=$ berat kapal diambil dari Displacement Tonnage (DT) kapal (ton), $\mathrm{V}=$ kecepatan kapal saat merapat $(\mathrm{m} / \mathrm{det}), C_{m}=$ koefisien massa virtual, $C_{e}=$ koefisien eksentrisitas, $C_{s}=$ koefisien kekerasan (umumnya bernilai 1), dan $C_{c}=$ koefisien konfigurasi tambat (umumnya bernilai 1).

Koefisien massa virtual bergantung pada volume yang ditempati oleh kapal dan dimensi kapal dan dihitung dengan Persamaan 4 dan 5 (The Overseas Coastal Area Development Institute of Japan (OCDI), 2002).

$$
C_{m}=1+\frac{\pi}{2 C_{b}} \frac{d}{b}
$$

Dengan $C_{m}=$ koefisien massa virtual, $\mathrm{d}=$ draft $\operatorname{kapal}(\mathrm{m})$, dan $C_{b}=$ koefisien blok kapal, $\mathrm{b}=$ lebar kapal.

$$
C_{b}=\frac{V}{L_{p p} \times b \times d}
$$

Dengan $C_{b}=$ koefisien blok kapal, $\mathrm{V}=$ volume air yang ditempati kapal $\left(\mathrm{m}^{3}\right), L_{p p}=$ panjang garis air $(\mathrm{m})$, $\mathrm{b}=$ lebar kapal (m), dan $\mathrm{d}=$ draft kapal (m).

Koefisien eksentrisitas merupakan perbandingan antara energi sisa dan energi kinetik dari kapal yang merapat. Koefisien eksentrisitas dihitung dengan Persamaan 6 dan 7 (The Overseas Coastal Area Development Institute of Japan (OCDI), 2002).

$$
C_{e}=\frac{1}{1+\left(\frac{l}{r}\right)^{2}}
$$

Dengan $C_{e}=$ koefisien eksentrisitas, $l=$ jarak permukaan air dari pusat berat kapal ke titik sandar kapal (m), dan $r=$ jari-jari putaran di sekeliling pusat berat kapal pada permukaan air $(\mathrm{m})$.

$$
r=\left(0,19 C_{b}+0,11\right) L_{p p}
$$

Dengan $r=$ jari-jari putaran di sekeliling pusat berat kapal pada permukaan air $(\mathrm{m}), C_{b}=$ koefisien blok kapal, dan $L_{p p}=$ panjang garis air $(\mathrm{m})$.

Nilai $l$ dapat dihitung dengan Persamaan 8 dan 9 (The Overseas Coastal Area Development Institute of Japan $(\mathrm{OCDI})$ ).

$$
\begin{aligned}
& \text { l dermaga }=\frac{1}{4} L_{o a} \\
& l \text { dolphin }=\frac{1}{6} L_{o a}
\end{aligned}
$$

Dengan $l=$ jarak permukaan air dari pusat berat kapal ke titik sandar kapal (m) dan $L_{o a}=$ panjang kapal yang dikur dari haluan kapal terdepan sampai buritan kapal paling belakang.

Gaya berthing pada dermaga segmen 1 diambil berdasarkan reaction fender dari nilai berthing force yang telah dihitung. 
Kapal yang merapat di dermaga akan ditambatkan dengan menggunakan tali ke alat tambat yang disebut bollard. Hal ini menghasilkan gaya tarikan kapal (mooring load) Pengikatan ini dimaksudkan untuk menahan gerakan kapal yang disebabkan oleh angin dan arus (Triatmodjo, 2010).

Gaya tarikan pada kapal pada alat tambat yang disebabkan oleh angin dan arus pada badan kapal disebut gaya tambat. Bollard pada dermaga harus mampu menahan gaya tarikan kapal. Gaya tarikan tersebut dapat ditentukan berdasarkan Tabel 1.

Tabel 1. Gaya tarikan kapal

\begin{tabular}{ccc}
\hline Gross Tonnage $(\mathrm{GT})$ & Gaya tarik pada tiang tambatan (ton) & Gaya tarik pada bollard (ton) \\
\hline $200<G T \leq 500$ & 15 & 15 \\
$500<G T \leq 1.000$ & 25 & 25 \\
$1.000<G T \leq 2.000$ & 35 & 25 \\
$2.000<G T \leq 3.000$ & 35 & 35 \\
$3.000<G T \leq 5.000$ & 50 & 35 \\
$5.000<G T \leq 10.000$ & 70 & 50 \\
$10.000<G T \leq 20.000$ & 100 & 70 \\
$20.000<G T \leq 50.000$ & 150 & 100 \\
$50.000<G T \leq 100.000$ & 200 & 100
\end{tabular}

(Sumber: The Overseas Coastal Area Development Institute of Japan (OCDI), 2002)

Beban gempa (earthquake load) adalah beban yang diakibatkan oleh pergerakan tanah yang disebabkan gempa bumi tektonik atau vulkanik. Gempa membebani struktur karena interaksi tanah dengan struktur dan karakteristik respons struktur. Beban gempa dihitung sesuai SNI 1726:2019 (Tata Cara Perencanaan Gempa untuk Bangunan Gedung dan Non-Gedung). Untuk menghitung gaya lateral desain total atau geser di dasar struktur menggunakan Persamaan 10.

$$
V=W \times C s
$$

Dengan $\mathrm{V}$ = gaya lateral desain total atau geser di dasar struktur $(\mathrm{kN}), \mathrm{W}=$ berat seismik efektif struktur, dan Cs $=$ koefisien gempa dasar.

Karena dermaga yang dimodel pada penelitian ini hanya segmen 1, maka gaya gempa yang dihitung hanya yang berlaku pada segmen 1 .

Beban yang bekerja akibat pengaruh struktur yang menghalangi aliran angin sehingga energi kinetik angin diubah menjadi tekanan energi potensial. Ini disebut beban angin (wind load) Pengaruh beban angin bergantung pada berat jenis dan kecepatan udara, sudut luas angin, bentuk dan kekakuan struktur, dan faktor-faktor yang lain. Beban angin dihitung dengan Persamaan 11 dan 12 (The Overseas Coastal Area Development Institute of Japan (OCDI)).

$$
\begin{gathered}
q=\frac{1}{2} \times \rho_{a} \times U^{2} \\
p=c \times q
\end{gathered}
$$

Dengan $q=$ velocity pressure $\left(\mathrm{kN} / \mathrm{m}^{2}\right), \rho_{a}=$ massa jenis udara $\left(\mathrm{kN} / \mathrm{m}^{3}\right), U=$ kecepatan angin $(\mathrm{m} / \mathrm{det}), p=$ gaya angin $(\mathrm{kN})$, dan $c=$ koefisien angin.

\section{Virtual fixed point}

Posisi virtual fixed point pada tiang pancang berada pada kedalaman $\frac{1}{\beta}$ di bawah virtual ground surface. Virtual ground surface adalah kedalaman dari nilai N. N adalah nilai rata-rata dari pukulan N-SPT dari seabed sampai titik kedalaman borlog yang digunakan. Virtual ground surface dapat dilihat pada Gambar 2. 


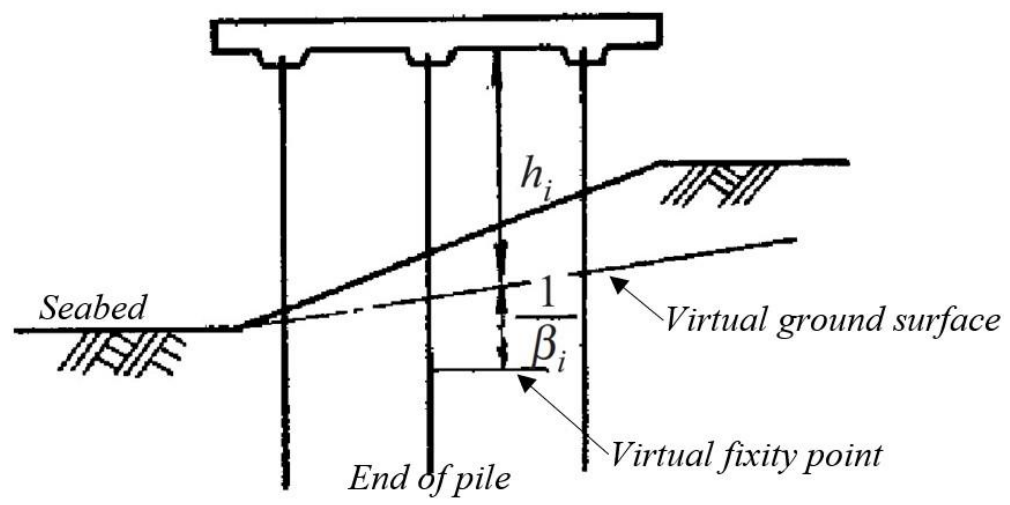

Gambar 2. Virtual ground surface (Sumber: OCDI, 2002)

Virtual fixed point $(\beta)$ dihitung menggunakan Persamaan 13 dan 14 (The Overseas Coastal Area Development Institute of Japan (OCDI)).

$$
\begin{gathered}
K h=1,5 \times N \\
\beta=\sqrt[4]{\frac{k_{h \times D}}{4 \times E \times I}}
\end{gathered}
$$

Dengan $K h=$ faktor koefisien dari reaksi dasar fondasi $\left(\mathrm{N} / \mathrm{cm}^{3}\right), N=$ nilai pukulan rata-rata pada N-SPT dari seabed sampai titik kedalaman borlog, $\beta=$ letak kedalaman titik virtual fixed point $\left(\mathrm{cm}^{-1}\right), D=$ diameter tiang $(\mathrm{cm}), E=$ modulus elastisitas tiang $\left(\mathrm{kg} / \mathrm{cm}^{2}\right)$, dan $I=$ momen inersia penampang tiang $\left(\mathrm{cm}^{4}\right)$.

Apabila tiang pancang yang digunakan berupa baja, maka nilai modulus elastisitas (E) adalah 200.000 MPa dan apabila berupa beton maka nilai modulus elastisitas dihitung menggunakan Persamaan 15 (SNI 2847:2019 (Persyaratan Beton Struktural untuk Bangunan Gedung dan Penjelasan)).

$$
E=4700 \times \sqrt{F^{\prime} C}
$$

Dengan $E=$ modulus elastisitas $(\mathrm{MPa})$ dan $F^{\prime} C=$ kuat tekan beton $(\mathrm{MPa})$.

Perhitungan rasio kekuatan gabungan tiang berdasarkan SNI 1729:2019 (Spesifikasi untuk Bangunan Gedung Baja Struktural) menggunakan Persamaan 16 dan 17.

Jika $\frac{P r}{P C} \geq 0,2$

$$
\text { Rasio }=\frac{P_{r}}{P_{c}}+\frac{8}{9} \times\left(\frac{M_{r x}}{M_{c x}}+\frac{M_{r y}}{M_{c y}}\right) \leq 1,0
$$

Jika $\frac{P r}{P c}<0,2$

$$
\text { Rasio }=\frac{P_{r}}{2 \times P_{c}}+\left(\frac{M_{r x}}{M_{c x}}+\frac{M_{r y}}{M_{c y}}\right) \leq 1,0
$$

Dengan $P_{r}=$ kekuatan aksial perlu $(\mathrm{kN}), P_{c}=$ kekuatan aksial tersedia $(\mathrm{kN}), M_{r}=$ kekuatan lentur perlu $(\mathrm{kNm})$, $M_{c}=$ kekuatan lentur tersedia $(\mathrm{kNm}), x=$ indeks sehubungan dengan sumbu kuat lentur, dan $y=$ indeks sehubungan dengan sumbu lentur.

\section{Kombinasi pembebanan}

Kombinasi pembebananan yang digunakan ditunjukkan pada Tabel 2 dan Tabel 3. 
Tabel 2. Kombinasi LRFD

\begin{tabular}{|c|c|c|c|c|c|c|c|c|}
\hline \multirow{2}{*}{$\begin{array}{c}\text { Load } \\
\text { Combination } \\
\end{array}$} & \multicolumn{8}{|c|}{ Load Case } \\
\hline & DL & SDL & LL & $\mathrm{C}$ & $\mathrm{Be}$ & M & Eqx & Eqy \\
\hline Comb 1 & 1,4 & 1,4 & - & - & - & - & - & - \\
\hline Comb 2 & 1,2 & 1,2 & 1,6 & - & - & - & - & - \\
\hline Сотb 3 & 1,2 & 1,2 & - & 1,2 & - & - & - & - \\
\hline Comb 4 & 1,2 & 1,2 & 1,6 & 1,2 & - & - & - & - \\
\hline Comb 5A & $1,0+\mathrm{k}$ & $1,0+\mathrm{k}$ & 0,1 & - & - & - & 1,3 & 0,39 \\
\hline Comb 5B & $1,0+\mathrm{k}$ & $1,0+\mathrm{k}$ & 0,1 & - & - & - & $-1,3$ & 0,39 \\
\hline Comb 5C & $1,0+\mathrm{k}$ & $1,0+\mathrm{k}$ & 0,1 & - & - & - & 1,3 & $-0,39$ \\
\hline Comb 5D & $1,0+\mathrm{k}$ & $1,0+\mathrm{k}$ & 0,1 & - & - & - & $-1,3$ & $-0,39$ \\
\hline Comb 5E & $1,0+\mathrm{k}$ & $1,0+\mathrm{k}$ & 0,1 & - & - & - & 0,39 & 1,3 \\
\hline Comb 5F & $1,0+\mathrm{k}$ & $1,0+\mathrm{k}$ & 0,1 & - & - & - & 0,39 & $-1,3$ \\
\hline Comb 5G & $1,0+\mathrm{k}$ & $1,0+\mathrm{k}$ & 0,1 & - & - & - & $-0,39$ & 1,3 \\
\hline Comb 5H & $1,0+\mathrm{k}$ & $1,0+\mathrm{k}$ & 0,1 & - & - & - & $-0,39$ & $-1,3$ \\
\hline Сотb 6А & $1,0-\mathrm{k}$ & $1,0-\mathrm{k}$ & 0,1 & - & - & - & 1,3 & 0,39 \\
\hline Сотb 6В & $1,0-\mathrm{k}$ & $1,0-\mathrm{k}$ & 0,1 & - & - & - & $-1,3$ & 0,39 \\
\hline Comb 6C & $1,0-\mathrm{k}$ & $1,0-\mathrm{k}$ & 0,1 & - & - & - & 1,3 & $-0,39$ \\
\hline Сотb 6D & $1,0-\mathrm{k}$ & $1,0-\mathrm{k}$ & 0,1 & - & - & - & $-1,3$ & $-0,39$ \\
\hline Сотb 6Е & $1,0-\mathrm{k}$ & $1,0-\mathrm{k}$ & 0,1 & - & - & - & 0,39 & 1,3 \\
\hline Comb 6F & $1,0-\mathrm{k}$ & $1,0-\mathrm{k}$ & 0,1 & - & - & - & 0,39 & $-1,3$ \\
\hline Сomb 6G & $1,0-\mathrm{k}$ & $1,0-\mathrm{k}$ & 0,1 & - & - & - & $-0,39$ & 1,3 \\
\hline Comb 6H & $1,0-\mathrm{k}$ & $1,0-\mathrm{k}$ & 0,1 & - & - & - & $-0,39$ & $-1,3$ \\
\hline Comb B1 & 1,2 & 1,2 & 1,6 & 1,2 & 1 & - & - & - \\
\hline Comb B2 & 1,2 & 1,2 & 1 & 1,2 & 1 & - & - & - \\
\hline Comb M1 & 1,2 & 1,2 & 1,6 & 1,2 & - & 1,6 & - & - \\
\hline Comb M2 & 1,2 & 1,2 & 1 & 1,2 & - & 1,6 & - & - \\
\hline Сотb М3 & 0,9 & 0,10 & - & 0,9 & - & 1,6 & - & - \\
\hline
\end{tabular}

(Sumber: UFC 4-152-01 Design: Piers and Wharves)

Tabel 3. Kombinasi ASD

\begin{tabular}{|c|c|c|c|c|c|c|c|c|}
\hline \multirow{2}{*}{$\begin{array}{c}\text { Load } \\
\text { Combination }\end{array}$} & \multicolumn{8}{|c|}{ Load Case } \\
\hline & DL & SDL & $\mathrm{LL}$ & $\mathrm{C}$ & $\mathrm{Be}$ & $\mathrm{M}$ & Eqx & Eqy \\
\hline Service 1 & 1 & 1 & - & - & - & - & - & - \\
\hline Service 2 & 1 & 1 & 1 & - & - & - & - & - \\
\hline Service 3 & 1 & 1 & - & 1 & - & - & - & - \\
\hline Service 4 & 1 & 1 & 1 & 1 & - & - & - & - \\
\hline Sevice 5A & $1,0+\mathrm{k}$ & $1,0+\mathrm{k}$ & 0,1 & - & - & - & 1 & 0,3 \\
\hline Service 5B & $1,0+\mathrm{k}$ & $1,0+\mathrm{k}$ & 0,1 & - & - & - & -1 & 0,3 \\
\hline Service 5C & $1,0+\mathrm{k}$ & $1,0+\mathrm{k}$ & 0,1 & - & - & - & 1 & $-0,3$ \\
\hline Service 5D & $1,0+\mathrm{k}$ & $1,0+\mathrm{k}$ & 0,1 & - & - & - & -1 & $-0,3$ \\
\hline Service 5E & $1,0+\mathrm{k}$ & $1,0+\mathrm{k}$ & 0,1 & - & - & - & 0,3 & 1 \\
\hline Service 5F & $1,0+\mathrm{k}$ & $1,0+\mathrm{k}$ & 0,1 & - & - & - & 0,3 & -1 \\
\hline Service $5 \mathrm{G}$ & $1,0+\mathrm{k}$ & $1,0+\mathrm{k}$ & 0,1 & - & - & - & $-0,3$ & 1 \\
\hline Sevice $5 \mathrm{H}$ & $1,0+\mathrm{k}$ & $1,0+\mathrm{k}$ & 0,1 & - & - & - & $-0,3$ & -1 \\
\hline Service 6A & $1,0-\mathrm{k}$ & $1,0-\mathrm{k}$ & - & - & - & - & 1 & 0,3 \\
\hline Service 6B & $1,0-\mathrm{k}$ & $1,0-\mathrm{k}$ & - & - & - & - & -1 & 0,3 \\
\hline Service 6C & $1,0-\mathrm{k}$ & $1,0-\mathrm{k}$ & - & - & - & - & 1 & $-0,3$ \\
\hline Service 6D & $1,0-\mathrm{k}$ & $1,0-\mathrm{k}$ & - & - & - & - & -1 & $-0,3$ \\
\hline Service 6E & $1,0-\mathrm{k}$ & $1,0-\mathrm{k}$ & - & - & - & - & 0,3 & 1 \\
\hline Service 6F & $1,0-\mathrm{k}$ & $1,0-\mathrm{k}$ & - & - & - & - & 0,3 & -1 \\
\hline Service 6G & $1,0-\mathrm{k}$ & $1,0-\mathrm{k}$ & - & - & - & - & $-0,3$ & 1 \\
\hline Service $6 \mathrm{H}$ & $1,0-\mathrm{k}$ & $1,0-\mathrm{k}$ & - & - & - & - & $-0,3$ & -1 \\
\hline Service 7 & 1 & 1 & 0,75 & 1,2 & - & - & - & - \\
\hline Service 8 & 1 & 1 & 1 & 1 & 1 & - & - & - \\
\hline Service 9 & 1 & 1 & 1 & 1 & - & 1 & - & - \\
\hline
\end{tabular}

(Sumber: UFC 4-152-01 Design: Piers and Wharves)

Dengan DL = beban mati, $\mathrm{SDL}=$ beban mati tambahan, $\mathrm{LL}=$ beban hidup, $\mathrm{C}=$ beban arus, $\mathrm{Be}=$ beban berthing, $\mathrm{M}=$ beban mooring, Eq = beban gempa, dan $\mathrm{k}=50 \%$ dari Peak Ground Acceleration (PGA). 
Lokasi penelitian adalah dermaga "SJ" di Bandar Lampung. Dimensi total dermaga rencana adalah sebesar $160 \mathrm{~m}$ x $9 \mathrm{~m}$. Dermaga terdiri dari 5 segmen jetty, 4 breasting dolphin, dan 1 mooring dolphin. Sisi selatan mengakomodasi kapal kargo 10.000 DWT dan sisi utara mengakomodasi kapal tongkang 5.000 DWT. Dimensi rencana struktur dermaga diperlihatkan pada Gambar 3.

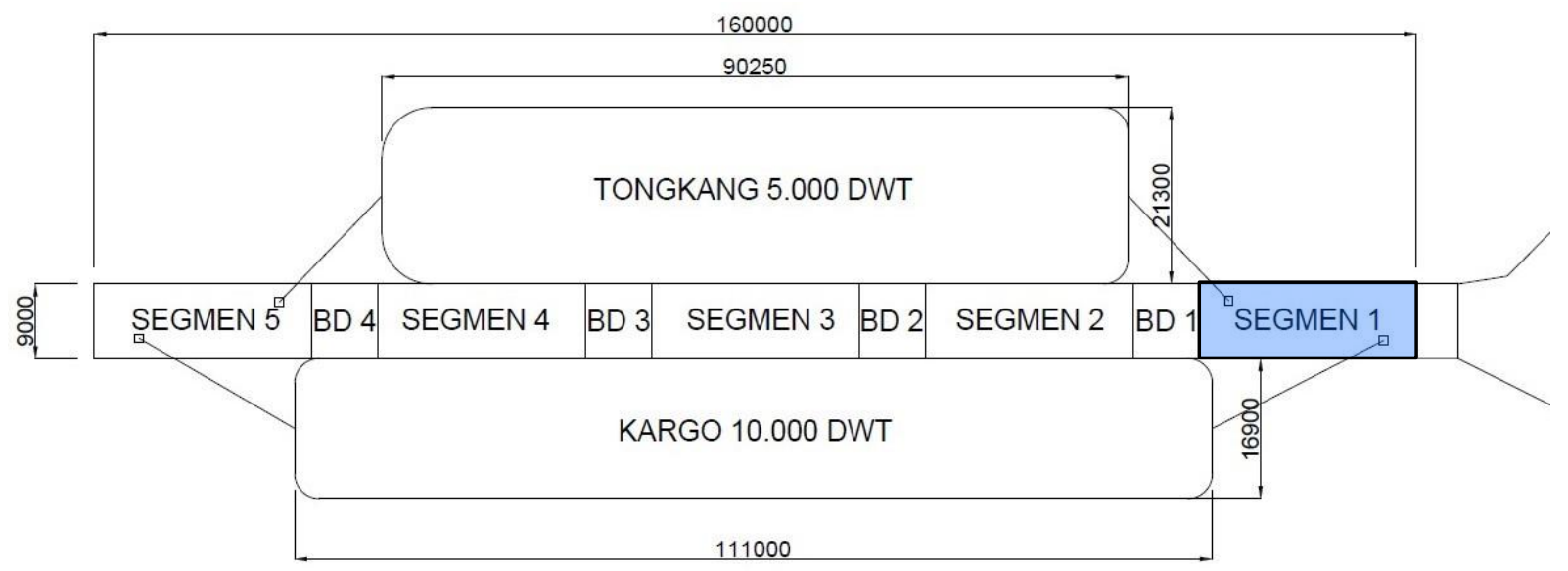

Gambar 3. Dimensi struktur dermaga “SJ” (Sumber: Laporan Desain Dermaga “SJ”, 2020)

Pada penelitian ini akan dimodel dermaga segmen 1 dengan 10 tipe konfigurasi tiang yaitu tipe 1 dengan konfigurasi tiang-tiang tegak seluruhnya, tipe 2 dengan tiang miring $1 \mathrm{H}: 12 \mathrm{~V}$, tipe 3 dengan tiang miring $1 \mathrm{H}: 11 \mathrm{~V}$, tipe 4 dengan tiang miring $1 \mathrm{H}: 10 \mathrm{~V}$, tipe 5 dengan tiang miring $1 \mathrm{H}: 9 \mathrm{~V}$, tipe 6 dengan tiang miring $1 \mathrm{H}: 8 \mathrm{~V}$, tipe 7 dengan tiang miring $1 \mathrm{H}: 7 \mathrm{~V}$, tipe 8 dengan tiang miring $1 \mathrm{H}: 6 \mathrm{~V}$, tipe 9 dengan tiang miring $1 \mathrm{H}: 5 \mathrm{~V}$, dan tipe 10 dengan tiang miring $1 \mathrm{H}: 4 \mathrm{~V}$.

\section{METODE PENELITIAN}

Data-data yang digunakan untuk analisis dermaga "SJ" terdiri dari:

1. Data spesifikasi material.

2. Data pembebanan dermaga.

3. Data hasil analisis struktur fondasi dermaga.

4. Data detail teknik proyek berupa gambar struktur.

Seluruh data yang disebutkan di atas diperoleh dari pihak konsultan dan pelaksana konstruksi dermaga "SJ".

Berikut langkah-langkah pengolahan data yang dilakukan:

1. Merencanakan konfigurasi tipe 1 hingga tipe 10. Tipe 1 dengan tiang tegak seluruhnya, tipe 2 dengan tiang miring $1 \mathrm{H}: 12 \mathrm{~V}$, tipe 3 dengan tiang miring $1 \mathrm{H}: 11 \mathrm{~V}$, tipe 4 dengan tiang miring $1 \mathrm{H}: 10 \mathrm{~V}$, tipe 5 dengan tiang miring $1 \mathrm{H}: 9 \mathrm{~V}$, tipe 6 dengan tiang miring $1 \mathrm{H}: 8 \mathrm{~V}$, tipe 7 dengan tiang miring $1 \mathrm{H}: 7 \mathrm{~V}$, tipe 8 dengan tiang miring $1 \mathrm{H}: 6 \mathrm{~V}$, tipe 9 dengan tiang miring $1 \mathrm{H}: 5 \mathrm{~V}$, tipe 10 dengan tiang miring $1 \mathrm{H}: 4 \mathrm{~V}$.

2. Membuat model konfigurasi tipe 1 hingga tipe 10 yang telah direncanakan di dalam program Midas Gen.

3. Memasukkan pembebanan yang sesuai dengan data perencanaan dermaga "SJ" ke dalam program Midas Gen.

4. Memasukkan kombinasi pembebanan yang sesuai dengan data perencanaan dermaga "SJ" ke dalam program Midas Gen.

5. Melakukan analisis untuk mendapatkan kekuatan (capacity ratio), kekakuan (defleksi), dan daya dukung aksial tiang dari masing-masing tipe konfigurasi tiang.

6. Memeriksa model di dalam Midas Gen secara optimal.

7. Melakukan pembahasan dan perbandingan hasil analisis dari konfigurasi tipe 1 hingga tipe 10 .

8. Memberikan kesimpulan dan saran dari hasil pembahasan. 


\section{HASIL DAN PEMBAHASAN}

Layout dan tampak depan dari masing-masing tipe konfigurasi ditunjukkan pada Gambar 4-6. Contoh dari model dermaga di dalam Midas Gen ditunjukkan pada Gambar 7.

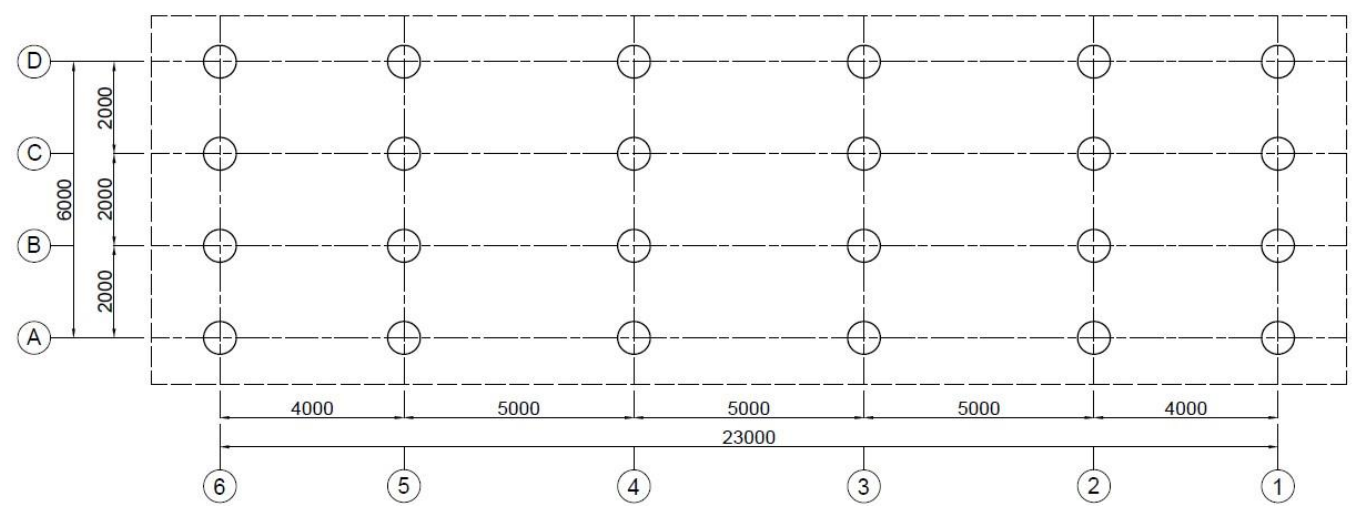

Gambar 4. Layout konfigurasi tiang tipe 1.

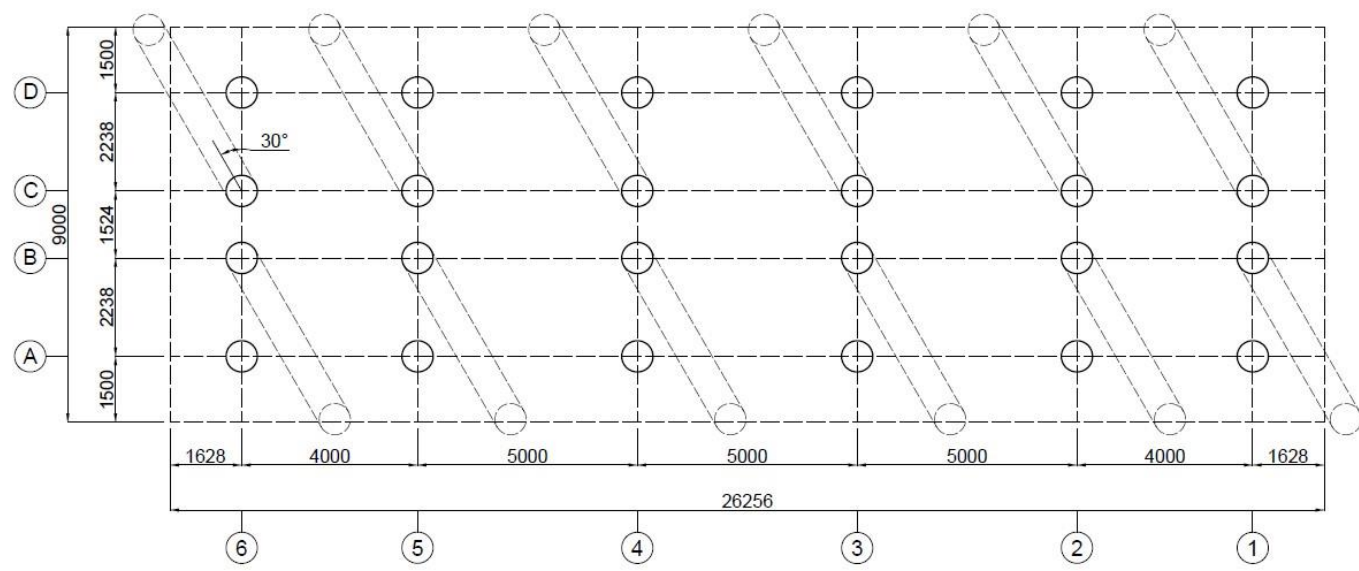

Gambar 5. Layout konfigurasi tiang tipe 2-10.
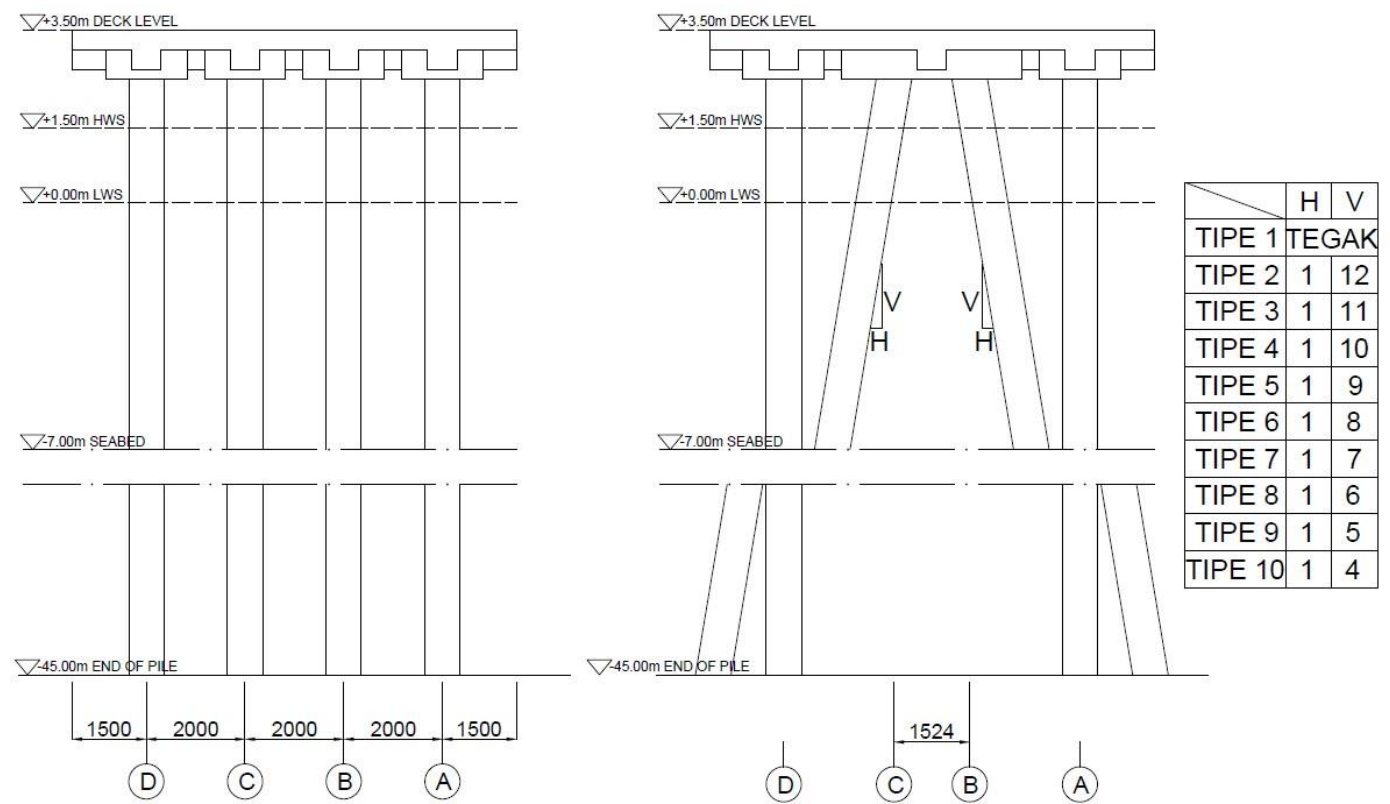

Gambar 6. Tampak depan konfigurasi tiang tipe 1-10. 


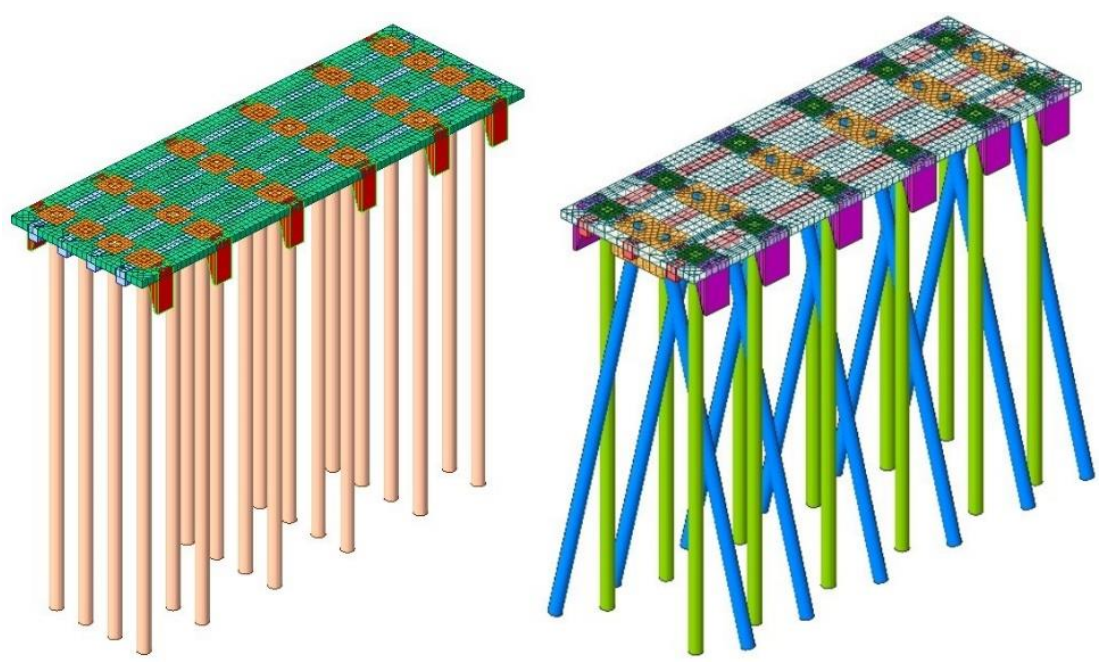

Gambar 7. Model dermaga konfigurasi tiang tipe 1 dan tipe 8 dalam Midas Gen.

Pembebanan yang dipergunakan ditunjukkan pada Tabel 4.

Tabel 4. Rencana pembebanan

\begin{tabular}{|c|c|c|c|c|}
\hline No & Beban & Kode & Besaran & Keterangan \\
\hline 1 & Mati & DL & 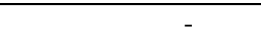 & Dihitung otomatis oleh program \\
\hline 2 & Mati tambahan & SDL & $\begin{array}{l}\text { Bollard }=1 \text { ton } \\
\text { Fender } \text { karet }=2 \text { ton }\end{array}$ & \\
\hline 3 & Hidup & LL & $3 \mathrm{ton} / \mathrm{m}^{3}$ & Beban terbagi rata \\
\hline 4 & Arus & $\mathrm{C}$ & $\varnothing 711=22,9 \mathrm{~kg} / \mathrm{m}^{2}$ & Kecepatan arus $0,2 \mathrm{~m} /$ detik \\
\hline 5 & Gempa & EQ & $\begin{array}{l}I=1 \\
R=3 \\
S d s=0,670 \\
S d 1=0,530 \\
\text { PGA }(k)=0,3892\end{array}$ & $\begin{array}{l}\text { Berdasarkan peta gempa } 2021 \\
\text { Dihitung hanya gaya gempa yang } \\
\text { berlaku pada segmen } 1\end{array}$ \\
\hline 6 & Berthing & $\mathrm{BE}$ & $\begin{array}{l}\mathrm{RF} 1=33,5 \text { ton } \\
\mathrm{RF} 2=41,2 \text { ton }\end{array}$ & $\begin{array}{l}\text { Untuk tongkang 5.000 DWT } \\
\text { Untuk kargo } 10.000 \mathrm{DWT}\end{array}$ \\
\hline 7 & Mooring & M & $\begin{array}{l}\text { M1 }: 35 \text { ton } \\
\text { M2 : } 50 \text { ton }\end{array}$ & $\begin{array}{l}\text { Untuk tongkang 5.000 DWT } \\
\text { Untuk kargo } 10.000 \text { DWT } \\
\text { Bekerja dengan sudut } 45^{\circ} \text { terhadap } \\
\text { horizontal dan vertikal }\end{array}$ \\
\hline
\end{tabular}

(Sumber: Laporan Desain Dermaga “SJ", 2020)

Perhitungan panjang tiang model (virtual fixed point) ditunjukkan pada Tabel 5.

Tabel 5. Virtual fixed point

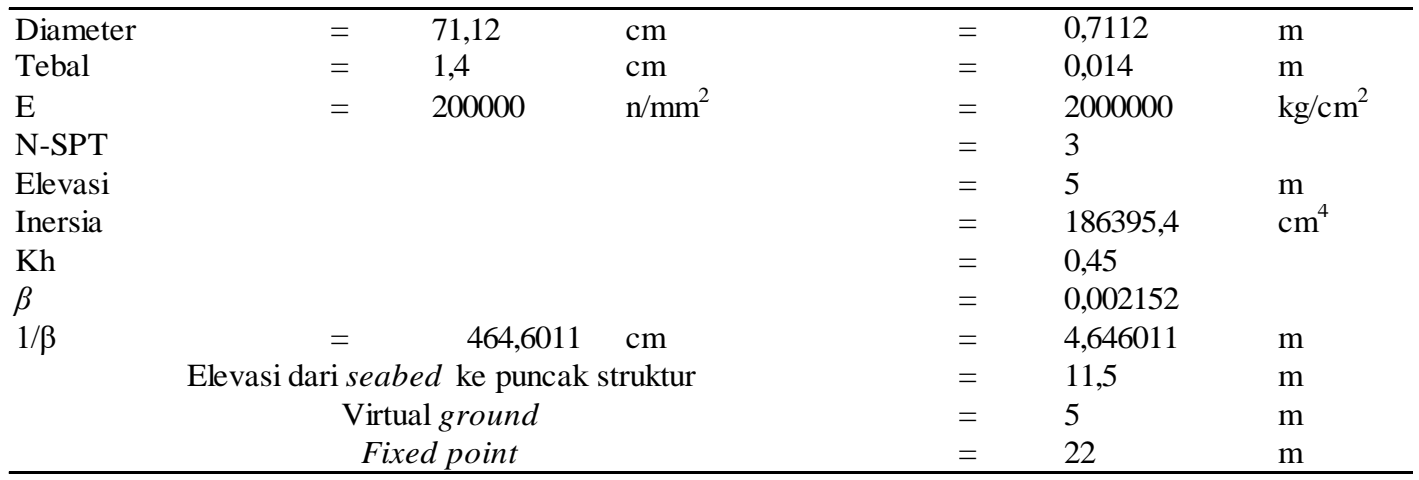

(Sumber: Laporan Desain Dermaga "SJ", 2020)

Capacity ratio tiang untuk konfigurasi tipe 1 hingga tipe 10 diperoleh antara 0,573 hingga 0,927 yang artinya telah memenuhi syarat karena lebih kecil dari 1. 
Defleksi ujung atas dermaga ditunjukkan pada Gambar 8 dan Gambar 9.

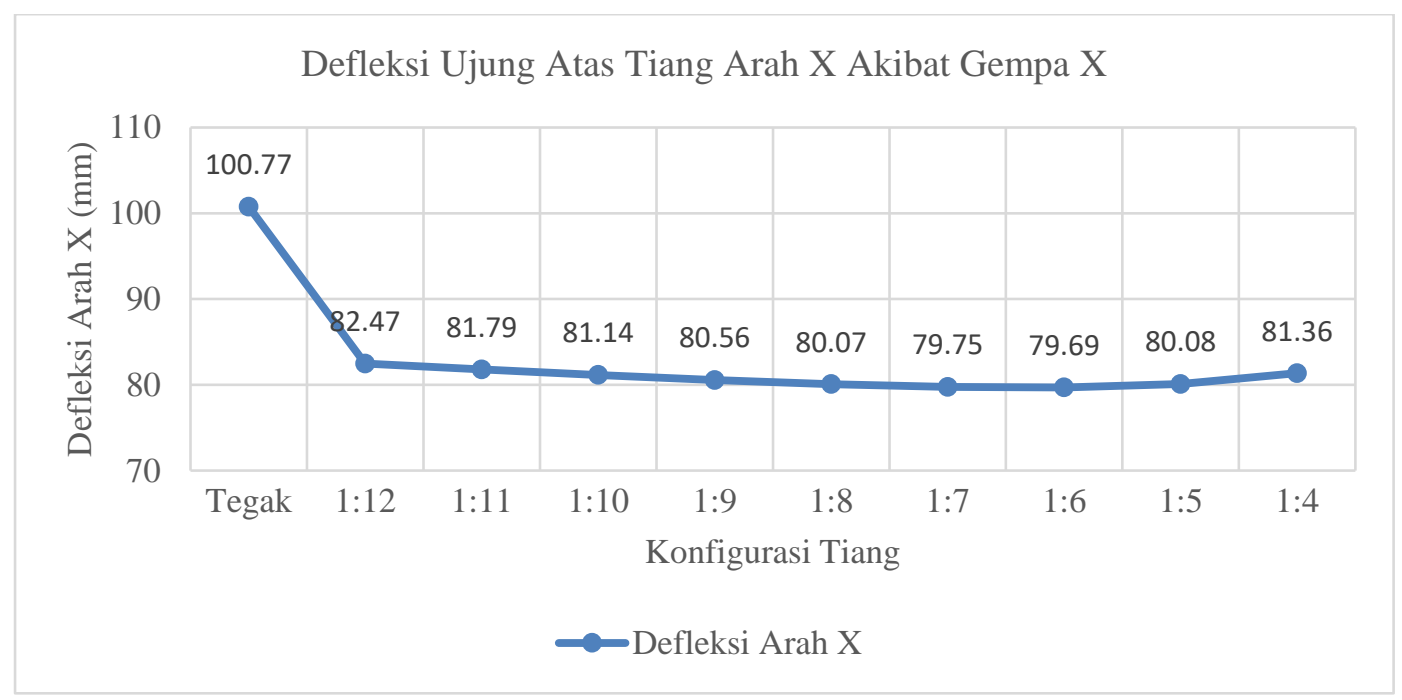

Gambar 8. Defleksi ujung atas tiang arah x akibat gempa x.

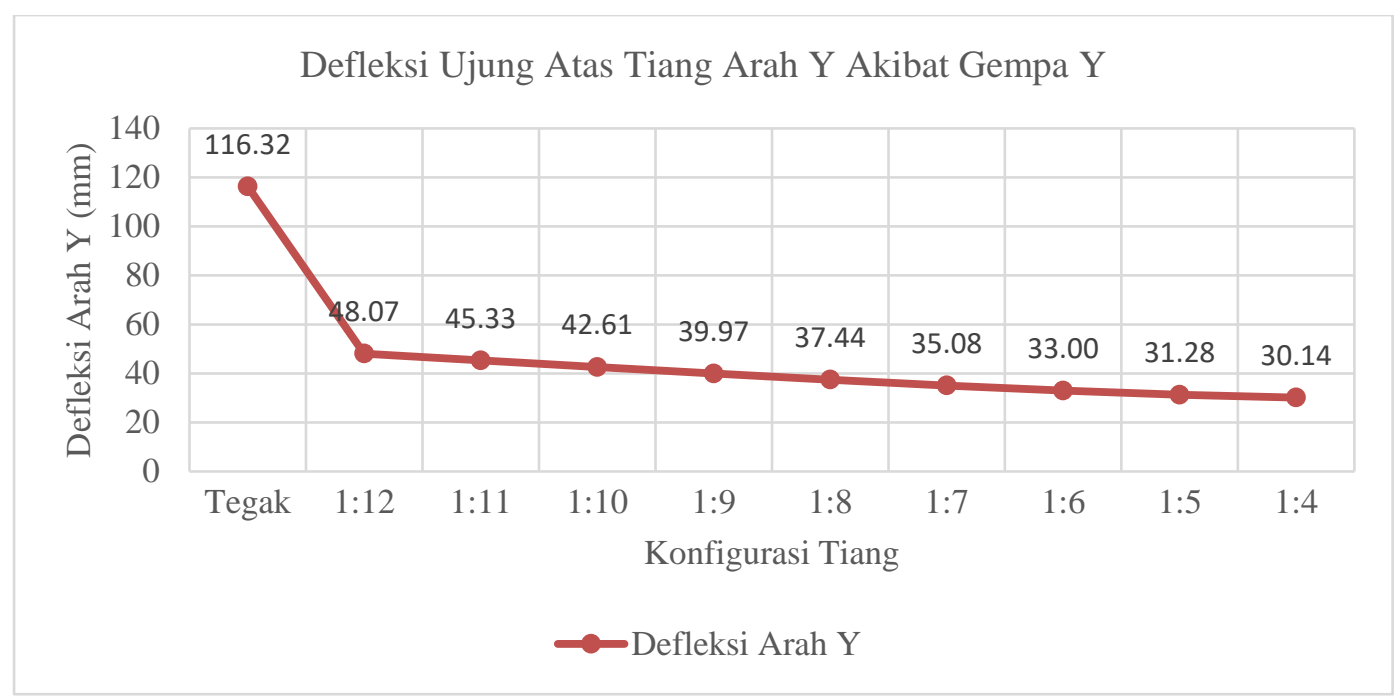

Gambar 9. Defleksi ujung atas tiang arah y akibat gempa y.

Defleksi ujung atas tiang mengalami penurunan yang cukup signifikan dari konfigurasi tiang tegak ke konfigurasi tiang dengan kombinasi tiang tegak dan miring. Kemudian defleksi arah x terus mengalami penurunan dari tipe 2 hingga tipe 9, kemudian dari tipe 8 hingga tipe 10 defleksi kembali mengalami peningkatan, dan untuk defleksi arah y terus mengalami penurunan seiring dengan semakin bertambah kemiringan tiang.

Defleksi ujung atas tiang arah $\mathrm{x}$ terkecil terjadi pada konfigurasi tipe 6 , tipe 7 , dan tipe 8 dengan kemiringan 1:8, 1:7, dan 1:6. Defleksi tipe 6 sebesar 80,17 mm, tipe 7 sebesar 79,83 mm, dan tipe 8 sebesar 79,75 mm. Ketiganya memiliki persentase perbedaan yang kecil yaitu sebesar $0,53 \%$.

Dalam pengecekan defleksi tiang pada konfigurasi tipe 1 terdapat tiang yang defleksi melebihi defleksi maksimum yang diizinkan yaitu $110 \mathrm{~mm}$. Tiang-tiang yang defleksi lebih besar daripada defleksi maksimum yang diizinkan adalah tiang nomor $6,12,18$, dan 24 dengan defleksi sebesar 117,86 mm, dan tiang nomor 5, 11, 17, dan 23 dengan defleksi sebesar 112,11 mm. Untuk konfigurasi tipe 2 hingga 10 tidak terdapat defleksi tiang yang lebih besar daripada defleksi maksimum yang diizinkan. 
Grafik dari gaya aksial tiang ditunjukkan pada Gambar 10-14.

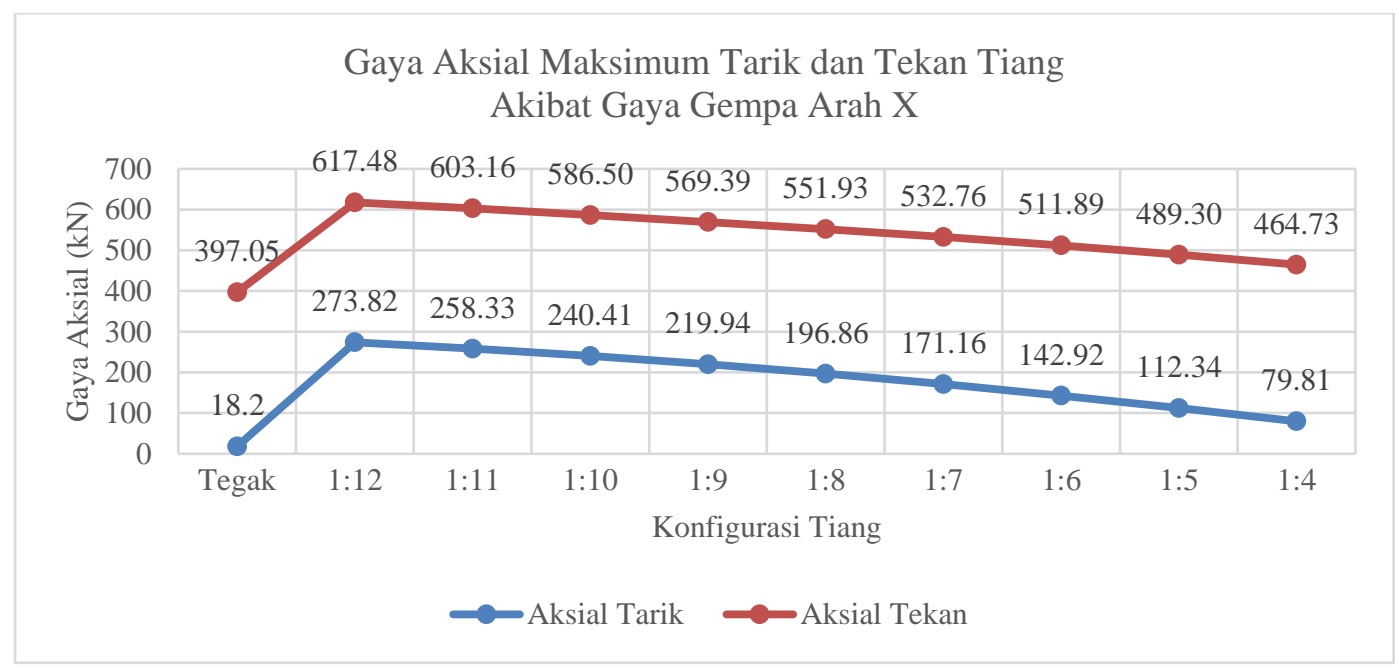

Gambar 10. Grafik gaya aksial maksimum tiang akibat gempa arah x.

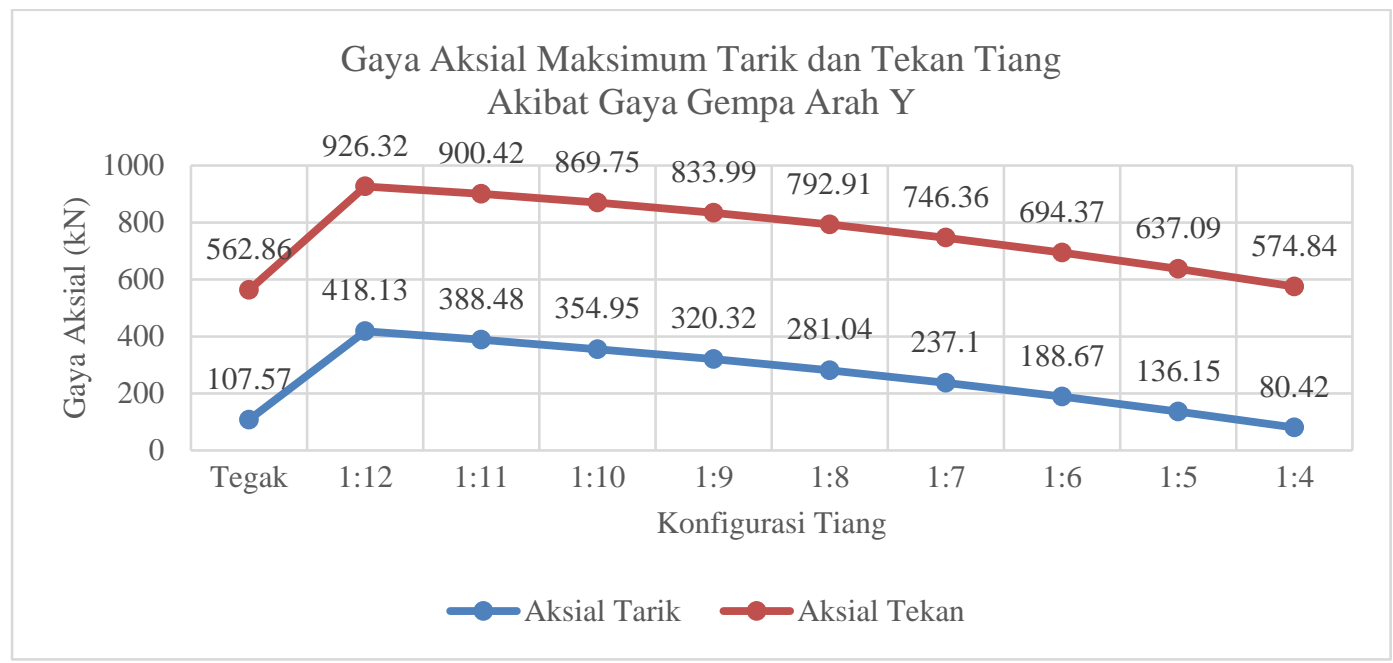

Gambar 11. Grafik gaya aksial maksimum tiang akibat gempa arah y.

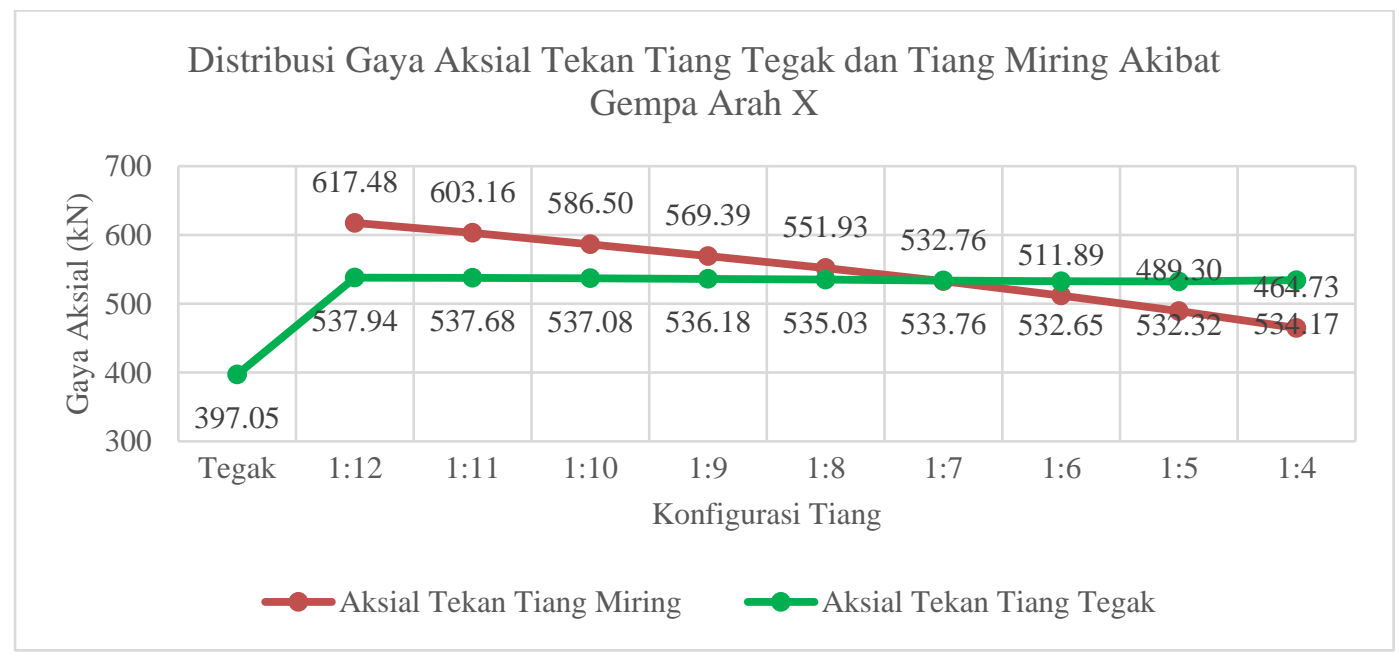

Gambar 12. Distribusi gaya aksial tekan tiang tegak dan tiang miring akibat gempa arah $\mathrm{x}$. 


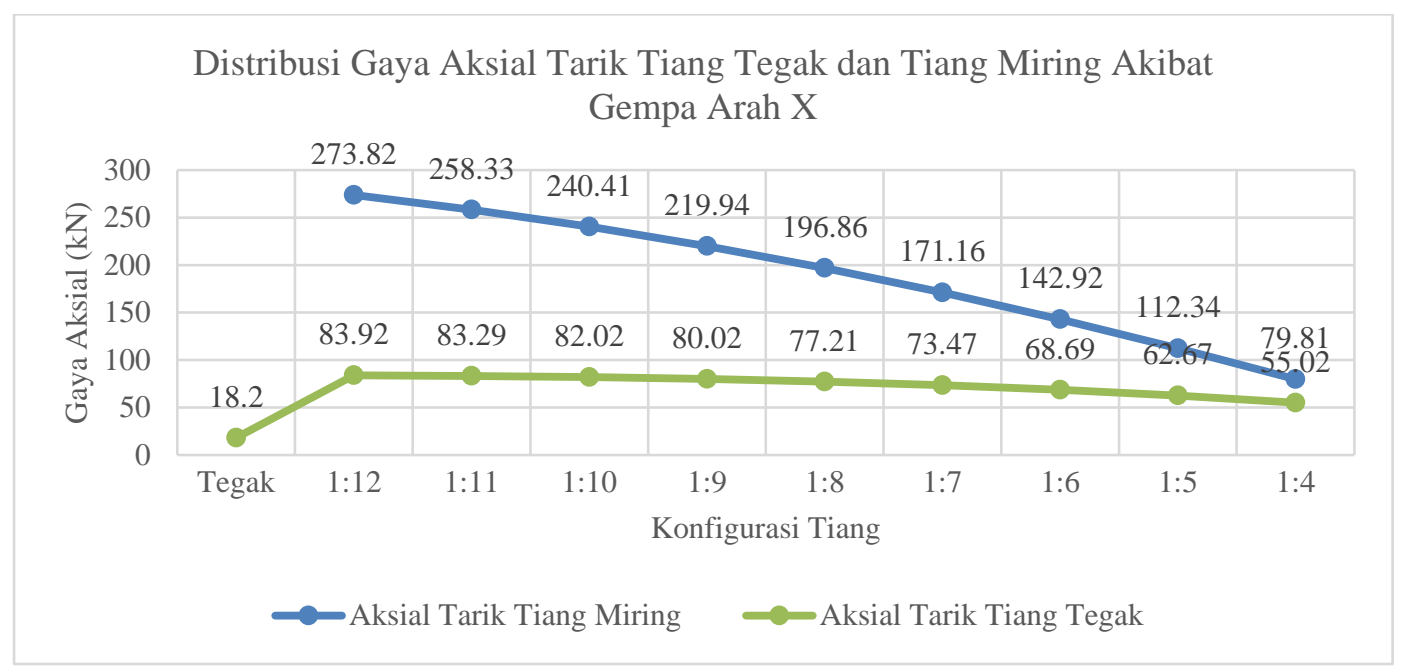

Gambar 13. Distribusi gaya aksial tarik tiang tegak dan tiang miring akibat gempa arah $\mathrm{x}$.

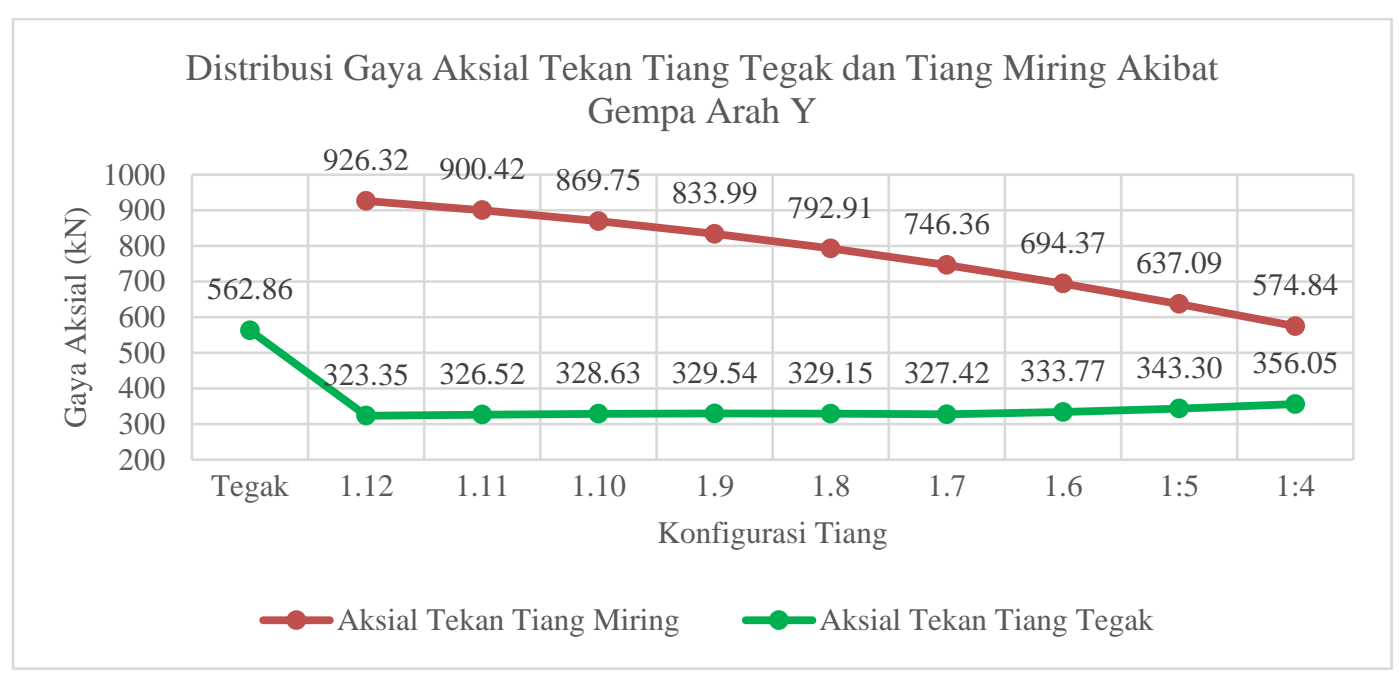

Gambar 14. Distribusi gaya aksial tekan tiang tegak dan tiang miring akibat gempa arah y.

Gaya aksial maksimum mengalami peningkatan cukup signifikan dari konfigurasi tiang tegak ke konfigurasi tiang dengan kombinasi tiang tegak dan miring, kemudian gaya aksial cenderung mengalami penurunan seiring dengan semakin bertambah kemiringan tiang.

Pada tiang tegak, gaya aksial akibat gempa arah x mengalami peningkatan cukup signifikan dari konfigurasi tiang tegak ke konfigurasi tiang dengan kombinasi tiang tegak dan miring. Sebaliknya akibat gempa arah y, gaya aksial mengalami penurunan dari konfigurasi tiang tegak ke konfigurasi tiang dengan kombinasi tiang tegak dan miring. Kemudian seiring bertambah kemiringan tiang, gaya aksial tiang tegak relatif sama dengan persentase perbedaan $0,05 \%$ hingga $12,21 \%$.

Terdapat konfigurasi tiang dengan gaya aksial tiang tegak dan tiang miring yang hampir sama dan menyebabkan grafik berpotongan, hal ini terjadi pada gaya aksial tekan akibat gempa arah x pada konfigurasi tipe 6 , tipe 7 , dan tipe 8 dengan kemiringan tiang 1:8, 1:7, dan 1:6. Pada tipe 6 gaya aksial sebesar 551,93 $\mathrm{kN}$ untuk tiang miring dan $535,03 \mathrm{kN}$ untuk tiang tegak, pada tipe 7 gaya aksial sebesar 535,76 kN untuk tiang miring dan $533,76 \mathrm{kN}$ untuk tiang tegak, dan pada tipe 8 gaya aksial sebesar $511,89 \mathrm{kN}$ untuk tiang miring dan $532,65 \mathrm{kN}$ untuk tiang tegak.

Konfigurasi tiang yang optimal berada di antara tipe 6, tipe 7, dan tipe 8 dengan kemiringan tiang 1:8, 1:7, dan 1:6. Dengan memperhatikan kesulitan dalam proses konstruksi, kemiringan batter pile tidak boleh lebih besar dari 1H:3V (Hannigan, Rausche, Likins, Robinson, \& Becker, 2016). Maka konfigurasi tiang tipe 8 dengan kemiringan tiang $1 \mathrm{H}: 6 \mathrm{~V}$ adalah konfigurasi tiang yang paling optimal. 


\section{KESIMPULAN DAN SARAN}

\section{Kesimpulan}

Setelah dilakukan analisis dan perbandingan antara 10 tipe konfigurasi tiang pancang, kesimpulan yang dapat diambil adalah:

1. Capacity ratio (rasio kekuatan gabungan) dari konfigurasi tipe 1 hingga tipe 10 diperoleh antara 0,573 hingga 0,927 yang artinya telah memenuhi syarat karena lebih kecil dari 1 .

2. Defleksi ujung atas tiang akibat gempa $\mathrm{x}$ dari konfigurasi tiang tegak ke tiang miring 1:12 mengalami penurunan sebesar $18,50 \%$ dari $101,44 \mathrm{~mm}$ ke $82,68 \mathrm{~mm}$.

3. Defleksi ujung atas tiang akibat gempa y dari konfigurasi tiang tegak ke tiang miring 1:12 mengalami penurunan sebesar $58,77 \%$ dari $118,44 \mathrm{~mm}$ ke $48,83 \mathrm{~mm}$.

4. Seiring bertambah kemiringan tiang, defleksi ujung atas tiang arah $\mathrm{x}$ dan $\mathrm{y}$ cenderung mengalami penurunan.

5. Gaya aksial tekan maksimum akibat gempa arah $\mathrm{x}$ dari konfigurasi tiang tegak ke tiang dengan kemiringan 1:12 mengalami peningkatan sebesar 55,52\%.

6. Gaya aksial tekan maksimum akibat gempa arah y dari konfigurasi tiang tegak ke tiang dengan kemiringan 1:12 mengalami peningkatan sebesar $64,57 \%$.

7. Gaya aksial maksimum akibat gempa arah $\mathrm{x}$ dengan semakin bertambah kemiringan tiang mengalami penurunan sebesar 5,66\% hingga $28,96 \%$ untuk tarik dan 2,32\% hingga 5,02\% untuk tekan.

8. Gaya aksial maksimum akibat gempa arah y dengan semakin bertambah kemiringan tiang mengalami penurunan sebesar 7,09\% hingga 40,93\% untuk tarik dan 2,80\% hingga 9,77\% untuk tekan.

9. Konfigurasi tiang tipe 8 dengan tiang miring 1:6 adalah konfigurasi terbaik dengan defleksi tiang terkecil serta gaya aksial tiang tegak dan tiang miring yang hampir sama.

\section{Saran}

Saran yang diusulkan setelah melakukan penelitian ini adalah melakukan penelitian lebih lanjut dengan model kondisi tanah dengan menggunakan spring pada tiang atau merubah arah kemiringan tiang terhadap sumbu horizontal.

\section{DAFTAR PUSTAKA}

Badan Standardisasi Nasional. (2015). SNI 1729:2019 Spesifikasi untuk Bangunan Gedung Baja Struktural. Jakarta: Badan Standardisasi Nasional.

Badan Standardisasi Nasional. (2019). SNI 1726:2019 Tata Cara Perencanaan Ketahanan Gempa untuk Struktur Bangunan Gedung dan Non-Gedung. Jakarta: Badan Standardisasi Nasional.

Badan Standardisasi Nasional. (2019). SNI 2847:2019 Persyaratan Beton Struktural untuk Bangunan Gedung dan Penjelasan. Jakarta: Badan Standardisasi Nasional.

Chegg Study. (2021, March). Definition of Batter. Retrieved from Chegg Study: https://www.chegg.com/homework-help/definitions/batter-8

Hannigan, P. J., Rausche, F., Likins, G. E., Robinson, B. R., \& Becker, M. L. (2016). Design and Construction of Driven Pile Foundations. Washington, D.C.: National Highway Institute.

Hardiyatmo, H. C. (2008). Teknik Fondasi 2. Yogyakarta: Beta Offset.

Murthy, V. (2002). Geotechnical Engineering: Principles and Practices of Soil Mechanics and Foundation Engineering. London: CRC Press.

PT Diagram Triproporsi. (2020). Laporan Desain Dermaga "SJ" - Bandar Lampung.

The Overseas Coastal Area Development Institute of Japan (OCDI). (2002). Technical Standards and Commentaries for Port and Harbour Facilities in Japan. Tokyo: Daikousha Printing Co., Ltd.

Triatmodjo, B. (2010). Perencanaan Pelabuhan. Yogyakarta: Beta Offset.

U.S. Department of Defense. (2017). UFC 4-152-01 Design: Piers and Wharves. U.S. Department of Defense. 

